\title{
Komposit Rumput Laut Dan Surimi Lele Terhadap Mutu Bakso
}

\author{
Seaweed And Surimi Catfish Composite On The Quality Of The Meatballs \\ Abdul Halik' ${ }^{1}$, Fatmawati ${ }^{*}$, Saiman Sutanto ${ }^{1}$, Suriana Laga ${ }^{1}$, Ramdanis $^{1}$ \\ *Email: fatmawati@universitasbosowa.ac.id \\ ${ }^{1}$ Program Studi Teknologi Pangan Fakultas Pertanian Universitas Bosowa
}

Diterima: 17 September 2021 / Disetujui: 24 Desember 2021

\begin{abstract}
ABSTRAK
Produksi rumput laut (Eucheuma cottonii) di Sulawesi Selatan meningkat signifikan dan berkontribusi terhadap total produksi di Indonesia. Namun peningkatan produksi belum dimanfaatkan secara maksimal khususnya pada bidang pangan. Fakta ini sangat berkaitan dengan strategi dalam pengololahan pasca panen. Salah satu strategi pengolahan diversifikasi produk pangan yakni membuat bakso dengan surimi ikan lele. Tujuan penelitian untuk menganalisis pengaruh komposit surimi ikan lele (Clarias) dan bubur rumput laut (Eucheuma cottonii), terhadap mutu bakso. Metode penelitian eksperimen, yang menggunakan Rancangan Acak Lengkap (RAL) dengan dua faktor dan empat perlakuan, yaitu: faktor A sebagai perlakuan persentase bubur rumput laut $(30 \%, 20 \%, 10 \%$, dan 0\%), sedangkan faktor B sebagai perlakuan persentase surimi lele $(45 \%, 55 \%, 65 \%$, dan $75 \%)$ dengan tiga kali ulangan. Parameter penelitian kadar protein, dan (uji sensorik dengan skalah hedonik) terhadap warna, aroma, tekstur, dan citarasa. Hasil penelitian diperoleh kandar protein bakso terendah 13,02\% dan tertinggi 19,95\% sehingga semua perlakuan memenuhi Syarat Mutu Bakso Ikan SNI No. 013818:2014. Sedangakan perlakuan 10\% bubur rumput laut dan 65\% surimi uji organoleptik memiliki nilai kesukaan warna (3,95/suka), aroma (3,93/suka), tekstur/kekenyalan (3,93/suka), dan citarasa $(4,12 /$ suka). Berdasarkan rerata nilai disimpulkan bahwa uji organoleptik bakso oleh panelis berada pada level suka.
\end{abstract}

Kata Kunci: Bakso, Ikan Lele, Rumput Laut

\begin{abstract}
The production of seaweed (Eucheuma cottonii) in South Sulawesi increased significantly and contributed to the total production in Indonesia. However, the increase in production has not been used optimally, in the food sector. This fact is closely related to strategies in post-harvest processing. One of the food product diversification processing strategies is the manufacture of meatballs with catfish surimi. The purpose of the study was to analyze the effect of the composite of catfish surimi (Clarias) and seaweed (Eucheuma cottonii), on the quality of meatballs. Experimental research method, using Completely Randomized Design (CRD) with two factors and four treatments, namely: factor $A$ as the percentage treatment of seaweed slurry (30\%, 20\%, 10\%, and 0\%), while factor B as the percentage treatment catfish surimi $(45 \%, 55 \%, 65 \%$, and $75 \%)$ with three replications. Research parameters protein content, and (sensory test with hedonic scale) on color, aroma, texture, and taste. The results obtained that the lowest protein content of meatballs was $13.02 \%$ and the highest was 19.95\% so that all treatments met the Quality Requirements for Fish Meatballs SNI No. 01-3818:2014. Meanwhile, the treatment of $10 \%$ seaweed porridge and $65 \%$ surimi organoleptic test had a preference value of color (3.95/like), aroma (3.93/like), texturelelasticity (3.93/like), and taste (4.12/like). Based on the average value that the organoleptic test of meatballs by the panelists, was at the level of liking.
\end{abstract}

Keywords: Meatballs, Catfish, Seaweed 


\section{A. PENDAHULUAN}

Kualitas produk pangan ditentukan oleh dua faktor yakni kandungan gizi oleh prodak tersebut, serta karakteristik prodak yang meliputih warna yang menarik, bentuk atau tekstur yang sesuai dengan sifat khas dari prodak, bahkan aroma juga yang tidak kalah pentingnya menggugah indera menciuman serta citarasa yang lezat. Oleh karena itu kelengkapan nutrisi yang terkandung dalam suatu makanan merupakan salah satu parameter utama penentu kualitas makanan tersebut. Namun dalam kenyataannya, karbohidrat secara umum masih mendominasi unsur gizi dalam makanan masyarakat. Menurut Potter dan Hotchkiss (2012) food quality atau kualitas makanan adalah karakteristik kualitas dari makanan yang dapat diterima oleh konsumen, seperti ukuran, bentuk, warna, konsistensi, tekstur, dan rasa. Makanan lezat dan segar memainkan peran penting dalam upaya memaksimalkan pemenuhan gizi masyarakat.

Ikan lele atau ikan keli (catfish) air tawar, selain harganya yang relatif murah dan mudah dibudidayakan sehingga sangat muda diperoleh, lele mempunyai struktur tulang yang mudah dilepaskan dari dagingnya serta memiliki tekstur yang alot sehingga baik untuk dibuat bakso, olehnya itu surimi lele cocok untuk dijadikan bahan baku berbagai produk olahan makanan, dinama struktur suriminya yang liat. Ikan lele sebagai sumber protein yang baik, mengandung lemak baik dan rendah kolestrol sehingga aman untuk dikomsumsi. Ikan lele juga megandung Vitamin D dan zat besi untuk mendukung pertumbuhan (Agustina, 2015).

Surimi adalah istilah yang berasal dari jepang yang menunjukan bentuk lumatan sebagai bahan dasar pengolahan produk tradisonal jepang "Kamaboko". Salah satu keunggulan surimi adalah kemampuannya untuk diolah menjadi berbagai macam produk lanjutan (Okada, et al., 2008). Surimi merupakan produk semi basah (konsentrat protein ikan). Pengolahan surimi yang baik akan menghasilkan produk dengan tingkat gel strength yang tinggi.

Menurut (Fitri, 2013) bahwa kriteria yang paling menentukan mutu surimi adalah elastisitas produk yang dihasilkan karena hasil pembentukan gel ikan. Faktor-faktor yang mempengaruhi elastisitas produk surimi diantaranya: jenis ikan, kesegaran ikan, $\mathrm{pH}$, kadar air, pencucian, suhu, dan waktu pemasakan dan jumlah zat penambah, seperti garam, gula, polipospat, monosodium glutamat, pati dan putih telur. Perlakuan pencincangan dan penggilingan juga menentukan tekstur (Herawati 2002). Klasifikasi surimi menurut Sazuki (2007) ditetapkan kedalam dua tipe yaitu: (a) $\mathrm{Mu}-$ en Surimi, dibuat dengan menggiling hancur 
surimi ikan yang telah dicuci dan dicampur gula tampah penambahan $\mathrm{NaCl}$ serta telah mengalami proses pembekuan. (b) Ka-en Surimi, dibuat dengan menggiling hancur surimi ikan yang telah dicuci dan dicampur gula dan garam dapur serta telah mengalami pembekuan. Selain surimi beku, terdapat tipe surimi lain yang disebut raw surimi yaitu surimi yang tidak mengalami proses pembekuan.

Produksi rumput laut yang melimpah di Indonesia utamanya di Sulawesi Selatan belum dimanfaatkan secara maksimal khususnya dalam bidang pangan (Fatmawati, et al., 2020). Selanjutnya karakteristik rumput laut jenis Eucheuma cottonii merupakan salah satu carragaenophtytes yaitu rumput laut penghasil karaginan mengandung serat (dietary fiber) sangat tinggi. Serat yang terdapat pada karaginan merupakan bagian dari serat gum larut dalam air, dan mampu membentuk gel dengan air panas, serta dapat membentuk pasta yang baik, berupa senyawa polisakarida, karena termasuk kedalam golongan Rhodophyta yang menghasilkan florin starch (Anggadiredja, 2011). Rumput laut sebagai sumber hidrokoloid karagenan dan merupakan polisakarida yang memiliki sifat sebagai pengenal, stabilisator, pembentuk gel dan pengemulsi pada industri pangan (Winarno, 1996). Jenis rumput laut
(Eucheuma cottonii) yang memiliki komposisi makro yaitu: protein $4,3 \%$, lemak 2,1\%, karbohidrat 90,9\%, serat pangan total $83,2 \%$, abu $2,7 \%$, dan karagenan 65,7\% (Astawan, et al.,2004). Komposisi kandungan micro rumput laut terdiri atas mineral esensial, asam nukleat, asam amino, dan vitamin A, D, C, D E, K, selain itu rumput laut banyak mengandung komponen hidrokoloid dalam bentuk agar, karagenan dan alginat, sehingga menghasilkan tekstur produk pangan yang kompak seperti pada tekstur bakso.

Bakso adalah produk pangan yang terbuat dari bahan utama daging yang dilumatkan, biasanya istilah bakso tersebut diikuti dengan nama jenis daging yang digunakan, seperti bakso ikan, bakso ayam dan bakso sapi, bakso tahu, bakso telur puyu, bakso udang (Fatmawati, et al., 2018). Selanjutnya Aprita, et al,. 2020 bahwa bakso merupakan produk makanan yang berbentuk bulatan yang diperoleh dari campuran surimi ternak atau surimi ikan. Berdasarkan bahan bakunya, terutama ditinjau dari jenis surimi dan jumlah tepung yang digunakan, bakso dibedakan menjadi tiga jenis yaitu bakso surimi, bakso urat, bakso aci.

Menurut (SNI, 2014) Bakso merupakan produk daging olahan yang terbuat dari daging ternak dan dicampur 
pati dengan bumbu-bumbu, tanpa atau dengan penambahan bahan pengisi lainnya. Kualitas bakso dapat ditentukan oleh penggunaan bahan pengisi (filler). Bahan pengisi yang sering digunakan yakni tapioka, selain tapioka dapat pula menggunakan bahan pengisi (filler) seperti rumput laut (Eucheuma cottonii). Penelitian ini dilakukan untuk mengetahui pengaruh komposit bubur rumput laut (Eucheuma cottonii) dan surimi lele terhadap (warna, aroma, tekstur, dan citarasa,) serta kadar protein bakso ikan lele yang paling disukai oleh konsumen/masyarakat.

\section{B. METODE PENELITIAN}

\section{Proses Pengolahan Bakso Ikan Lele}

Prosedur pembuatan bakso berdasarkan modifikasi (Fatmawati, et al., 2018). Pembersihan ikan lele segar dari isi perut, kepala, duri dan kulit dengan menggunakan pisau stainless steel. Penggilingan daging ikan lele menjadi surimi menggunakan mesin (meat grinder), hingga ikan lele halus.

Pengolahan bubur rumpur laut yaitu perendaman rumput laut kering selama 10 menit dengan air tawar, kemudian pemotong sepanjang $\pm 2 \mathrm{~cm}$, pencucian sampai bersih/putih dan peniriskan \pm 5 menit. Pengukusan 15 menit (lunak), selanjutnya penggilingan menggunakan blender.

Penimbangan bahan sesuai perlakuan $\mathrm{P}_{1}$ (750 gram surimi lele, tanpa bubur rumput laut), $\mathrm{P}_{2}$ (650 gram surimi lele, 100 gram bubur rumput laut), $\mathrm{P}_{3}$ (550 gram surimi lele, 200 gram bubur rumput laut,), $\mathrm{P}_{4}$ (450 gram surimi lele, 300 gram bubur rumput laut,), $\mathrm{P}_{5}$ (350 gram surimi lele, 400 gram bubur rumput laut).

Pencampuran setiap perlakuan masing-masing penambahan 25 gram tepung tapioka, bawang goreng 3 gram, bawang putih 5 gram yang telah halus, lada bubuk 3 gram, garam halus 5 gram, es batu 10 gram, dan telur 1 butir.

Penambahan tepung tapioka keadonan pada mesin penggiling sedikit demi sedikit sampai adonan tercampur merata/homogen. Pencetakan bakso secara manual menunggunakan sendok makan, kemudian kedalam panci yang berisi air suhu $40-70^{\circ} \mathrm{C} \pm 15$ menit, hingga bakso terapung, perebusan dilanjutkan dengan suhu $100^{\circ} \mathrm{C}$ selama 10 menit yang bertujuan untuk pematangan, bakso matang diangkat sambil ditiriskan kemudian pendinginan, selanjutnya pengujian organoleptik bakso oleh panelis terhadap warana, aroma, tekstur, citarasa, dan kadar protein dengan uji kimia di laboratorium. 
2. Analisis Kadar Protein (AOAC, 2001)

Metode penetapan kadar protein menggunakan metode Kjeldahl yaitu: Penimbangan sampel 1 gram kedalam labu kjeldahl, penambahan 7 gram $\mathrm{K}_{2} \mathrm{SO}_{4}, 0,8$ gram $\mathrm{CuSO}_{4}$, dan $\mathrm{H}_{2} \mathrm{SO}_{4} 12 \mathrm{ml}$, pelaksanaan di lemari asam. Proses destruksi sampel hingga diperoleh larutan berwarna hijau toska, pendinginan labu Kjeldal selama 20 menit. Penambahan 25 $\mathrm{ml}$ aquades dalam labu Kjeldahl berisi sampel, dan $50 \mathrm{ml} \mathrm{NaOH} \mathrm{40 \% ,} \mathrm{serta}$ beberapa butir batu didih (proses destilasi).

Asam boraks $\left(\mathrm{H}_{3} \mathrm{BO}_{3}\right) \quad 30 \mathrm{ml}$ kedalam elenmeyer dan ditambahkan indikator BCG-MR 3 tetes untuk menampung hasil destilasi. Destilat kemudian dititrasi menggunakan larutan standar $\mathrm{HCl}$ 0,1 $\mathrm{N}$ hingga warna larutan menjadi merah muda. Prosedur yang sama untuk blanko dan sampel diganti dengan aquades.

Perhitungan:

protein\% $=\frac{m l \text { HCl (Sampel }- \text { Blanko) }}{\text { Berat Sampel }(g)} \times N H C l \times 14,008 \times 100 \%$

Ket: $\mathrm{N}=$ Normalitas $\mathrm{HCl}$

Faktor koreksi protein $=14,008$.

3. Uji Organoleptik (Iswendi, et al., 2019)

Tabel 1. Hasil Penelitian Komposit Bubur Rumput Laut (Eucheuma Cottonii) dan Surimi Pada Pembuatan Bakso Ikan Lele.
Uji organoleptik berkaitan dengan penerimaan konsumen suka atau tidak suka terhadap produk pangan yang dihasilkan. Alat pengukuran daya penerimaan menggunakan indra manusia atau uji sensori. Metode pengujian menggunakan skala hedonik (uji kesukaan) dengan skala 1 sampai 5, yaitu sangat tidak suka dengan nilai 1 , tidak suka dengan nilai 2, agak suka dengan nilai 3 , suka dengan nilai 4, dan sangat suka dengan nilai 5 .

Pengujian organoleptic menggunakan tingkat kesukaan panelis terhadap produk bakso. Panelisnya setengah terlatih dari mahasiswa Teknologi Pangan Universitas Bosowa Makassar sebanyak 25 orang, yang memberikan penilaian berdasarkan tingkat kesukaannya terhadap bakso ikan lele. Parameter yang diukur meliputi: warna, aroma, tekstur dan citarasa.

\section{HASIL DAN PEMBAHASAN}

Hasil penelitian produk bakso ikan lele dengan berbagai komposit rumput laut Eucheuma cottoni dan surimi ikan lele. Hasil rataan penelitian pembuatan bakso ikan lele terhadap uji organoleptik warna, aroma, tekstur, citarasa, dan kadar protein. Disajikan pada tabel 1. 


\begin{tabular}{cccccc}
\hline $\begin{array}{c}\text { Surimi Lele: } \\
\text { Rumput } \\
\text { Laut)\% }\end{array}$ & Warna & Aroma & Tekstur & Citarasa & Kadar Protein(\%) \\
\hline P1 (75:0) & 3,72 & 3,64 & 3,62 & 3,73 & 20,67 \\
P2 (65:10) & 3,95 & 3,93 & 3,93 & 4,12 & 19,95 \\
P3 (55:20) & 3,94 & 3,83 & 3,74 & 3,92 & 17,07 \\
P4 (45:30) & 3,83 & 3,84 & 3,82 & 3,84 & 15,82 \\
P5 (35: 40) & 3,82 & 3,82 & 3,91 & 3,75 & 13,02 \\
\hline
\end{tabular}

\section{Kadar Protein}

Hasil analisa pada tabel 1, kadar protein bakso ikan lele dengan perlakuan komposit rumput laut dan surimi, berkisar antara (13,02 sampai 20,67)\%. Kadar protein menurun seiring dengan besarnya konsentrasi rumput laut yang ditambahkan dalam pengolahan bakso, namun sebaliknya semakin tinggi jumlah penambahan surimi dalam pengolahan, maka kadar protein bakso juga semakin meningkat. Berdasarkan hasil sidik ragam diperoleh bahwa komposit rumput laut dan surimi pada pembuatan bakso berpengaruh sangat nyata terhadap kadar protein bakso ikan lele yang dihasilkan, dimana nilai sig $(0,00 \leq 0,05)$. Selanjutnya hasil uji beda nyata terkecil diperoleh bahwa perlakuan $75 \%$ surimi dan $0 \%$ rumput laut terhadap $65 \%$ surimi dan $10 \%$ rumput laut tidak memberikan pengaruh yang berbeda (sig 0,12> 0,05), namun memberikan pengaruh berbeda (sig $0,00 \leq 0,05)$ terhadap 55\% surimi dan 20\% rumput laut; juga terhadap $45 \%$ surimi dan $30 \%$ rumput laut; begitupulan terhadap 35\% surimi dan $40 \%$ rumput laut pada kadar protein bakso.

Menurut SNI No. 7266 - 2014 bahwa syarat mutu bakso salah satunya adalah kandungan protein. Kadar protein bakso surimi dan bakso surimi kombinasi minimal $8 \%(\mathrm{~b} / \mathrm{b})$ dan $11 \%(\mathrm{~b} / \mathrm{b})$ untuk bakso surimi bukan kombinasi. Hasil penelitian diperoleh bahwa kandungan protein semua perlakuan memenuhi standar SNI, dimana hasilnya berkisar antara $(13,02$ sampai 20,67$) \%$. Menurut Pinardi, et al., 2020 bahwa semakin tinggi komposisi surimi dalam pengolahan sosis maka semakin tinggi kandungan proteinnya, dan sebaliknya semakin tinggi penambahan kacang merah maka semakin rendah kandungan proteinya. Herawati (2008) bahwa pengunaan suhu tingi dan lama waktu perebusan dan pengukusan dapat mengakibatkan kerusakan protein.

Protein merupakan makromolekul polipeptida tersusun dari sejumlah L-asam amino yang dihubungkan oleh ikatan peptida. Protein dalam makanan nabati terlindung oleh dinding sel yang terdiri 
atas selulosa sehingga daya cerna sumber protein nabati pada umumnya lebih rendah dibandingkan dengan sumber protein hewani (Probosari, 2019), selanjutnya Winarno, 1997 bahwa protein merupakan suatu zat makanan yang sangat penting bagi tubuh, karena berfungsi sebagai bahan bakar dalam tubuh dan sebagai zat pembangun serta zat pengatur. Protein dapat digunakan sebagai sumber energi cadangan apabila keperluan energi tubuh tidak terpenuhi oleh karbohidrat dan lemak. Sebagai zat pembangun dan pengatur, dalam pembentukan jaringan baru serta berfungsi untuk mempertahankan jaringan yang telah ada di dalam tubuh manusia.

\section{Uji Organoleptik Warna Bakso}

Hasil analisa pada tabel 1, warna bakso ikan lele dengan perlakuan komposit rumput laut dan surimi, berkisar antara (3,72 sampai 3,95). Hasil uji tingkat kesukaan panelis terbaik pada perlakuan $65 \%$ surimi : $10 \%$ rumput laut, dengan nilai 3,95 pada skala hedonik dibulatkan menjadi 4 sehingga berada pada taraf suka. Sedangkan hasil terendah kesukaan panelis pada perlakuan $75 \%$ surimi ikan lele: $0 \%$ rumput laut, yaitu 3,72 atau agak suka namun jika dibulatkan menjadi 4 , maka juga berada pada taraf suka.
Warna bakso hasil pengamatan panelis berwarna gelap agak keputihputihan, hal ini dipengaruhi oleh warna surimi ikan lele, seperti dijelaskan oleh Wulandhari (2007) bahwa Warna bakso dipengaruhi oleh bahan pengisi dan bahan pengikat yang ditambahkan. Penambahan dalam jumlah besar dapat menyebabkan warna produk menjadi kecoklatan sehingga menurunkan mutu sensori warna pada produk akhir. Sedangkan penambahan rumput laut tidak memberikan pengaruh terhadap warna bakso, karena warna rumput laut netral sehingga tidak memberikan pengaruh warna terhadap bakso ikan lele.

Hasil analisis keragaman warna bakso menunjukkan bahwa perlakuan komposit rumput laut dan surimi tidak berpengaruh terhadap warna bakso ikan lele yang dihasilkan, dimana nilai sig $(0,395 \geq 0,05)$. Selain itu tepung tapioka cukup baik digunakan sebagai bahan pembantu pewarna putih (Whister, dkk, 1984).

Hasil penelitian ini sejalan dengan penelitian dari Lova dan Leily (2015) bahwa bakso surimi sapi dengan penambahan rumput laut tidak memberikan pengaruh terhadap warna bakso. Akan tetapi berbeda dari hasil penelitian Puspitasari (2008) bahwa bakso 
dengan penambahan rumput laut memberikan pengaruh terhadap warna bakso. Menurut Setyaningsih, et al. (2010), secara visual warna merupakan faktor yang paling cepat memengaruhi kesan dan penerimaan dari suatu produk.

\section{Uji Organoleptik Aroma Bakso}

Hasil analisa pada tabel 1. Aroma bakso ikan lele dengan perlakuan komposit rumput laut dan surimi, berkisar antara (3,64 sampai 3,95). Hasil uji tingkat kesukaan panelis tertinggi pada perlakuan $35 \%$ surimi: $40 \%$ rumput laut, dengan nilai 3,95 pada skala hedonik dibulatkan menjadi 4 sehingga berada pada taraf suka. Sedangkan hasil terendah tingkat kesukaan panelis pada perlakuan $65 \%$ surimi: $10 \%$ rumput laut, yaitu 3,82 atau agak suka namun jika dibulatkan menjadi 4, maka juga berada pada taraf suka.

Hasil pengujian sidik ragam aroma bakso ikan lele menunjukkan bahwa komposit rumput laut dan surimi berpengaruh nyata terhadap aroma bakso ikan lele yang dihasilkan dimana nilai sig $0,009 \leq 0,05$, kemudian berdasarkan uji lanjut Beda Nyata Terkecil aroma bakso ikan lele diperoleh hasil uji beda nyata bahwa perlakuan P1 terhadap P2 dan P3 serta P5 tidak berbeda nyata dimana nilai sig $\leq 0,05$ sedangkan $\mathrm{P} 1$ terhadap P4 berbeda nyata dengan nilai sig $0,097 \geq 0,05$.

Aroma bakso yang dominan yakni aroma ikannya, karena ikan lele merupakan salah satu jenis ikan yang aromanya sangat kuat, sehingga mempengaruhi aroma produk olahan, dan rumput laut memiliki aroma amis tetapi tidak terlalu kuat, karena zat volatilnya mudah menguap pada proses perendaman, pencucian, dan pengkusan. Selain itu tepung tapioka juga merupakan tepung yang tidak berbau (Maharaja, et al,. 2008). Menurut Soekarto (1985) aroma merupakan pencicipan jarak jauh, dimana manusia dapat mencium enaknya makanan yang belum terlihat atau belum termakan, hal itu karena adanya sel-sel epitel alfaktori dibagian hidug atas rongga hidung yang peka terhadap komponen bau. Aroma bakso dipengaruhi oleh aroma daging, aroma tepung bahan pengisi, bumbu-bumbu dan bahan lain yang ditambahkan. Pemasakan dapat mempengaruhi warna, bau, rasa dan produk daging (Sudrajat, 2007).

\section{Uji Organoleptik Tekstur Bakso}

Hasil analisa pada tabel 1. Tekstur bakso ikan lele dengan perlakuan komposit rumput laut dan surimi, berkisar antara (3,62 sampai 3,93). Hasil uji tingkat kesukaan panelis tertinggi pada perlakuan 
$65 \%$ surimi: $10 \%$ rumput laut, dengan nilai 3,93 pada skala hedonik dibulatkan menjadi 4 sehingga berada pada taraf suka. Sedangkan hasil terendah pada tingkat kesukaan panelis diperlakuan 55\% surimi: $20 \%$ rumput laut, yaitu 3,74 atau agak suka namun jika dibulatkan menjadi 4 , dengan demikian berada pada taraf suka. Hasil sidik ragam tekstur bakso ikan lele menunjukkan bahwa komposit rumput laut dan surimi tidak berpengaruh terhadap tekstur bakso ikan lele yang dihasilkan dimana nilai sig $(0,031 \geq 0,05)$.

Aspek yang dinilai dari tekstur bakso yaitu kasar, halus dan kenyal seperti yang sampaikan oleh (Soeparno, 2005) bahwa penilaian tekstur suatu produk pangan dari aspek kasar atau halusnya produk. Tekstur mempunyai peranan penting pada daya terima konsumen. Penilaian terhadap tekstur antara lain kehalusan dan kekenyalan, serta keadaan fisik oleh indera penglihatan dan perabaan (Carpenter et al, 2000). Selain itu tekstur bakso dipengaruhi oleh kandungan air, jenis karbohidrat sebagai bahan pengikat, dan lemak tinggi akan menghasilkan bakso yang berlubanglubang sehingga dapat mempengaruhi tektur bakso (Octavianie, 2002). Kemudian (Anggraeni et al, 2020) bahwa penambahan berbagai konsetrasi bubur rumput laut berpengaruh terhadap sifat fisik bakso puyu, dan penggunaan $10 \%$ bubur rumput laut menghasilkan penerimaan paling disukai oleh panelis terhadap aroma, tekstur, dan citarasa bakso puyu.

\section{Uji Organoleptik Citarasa Bakso}

Hasil analisa pada tabel 1. Citarasa bakso ikan lele dengan perlakuan komposit bubur rumput laut dan surimi lele, berkisar antara $(3,73$ sampai 4,12). Hasil uji tingkat kesukaan panelis tertinggi pada perlakuan $65 \%$ surimi lele: $10 \%$ bubur rumput laut, dengan nilai 4,12 pada skala hedonik dibulatkan menjadi 4 sehingga berada pada taraf suka. Sedangkan hasil terendah pada tingkat kesukaan panelis yakni perlakuan $35 \%$ surimi lele: $40 \%$ bubur rumput laut, yaitu 3,75 atau agak suka namun jika dibulatkan menjadi 4 , maka juga berada pada taraf suka. Berdasarkan hasil pencicipan panelis citarasa bakso yang dihasilkan bervariasi, semakin banyak surimi lele yang digunakan penerimaan panelis semakin tinggi nilai kesukaannya, sebaliknya semakin banyak bubur rumput laut yang digunakan daya penerimaan panelis semakin berkurang.

Hasil sidik ragam menunjukkan bahwa komposit bubur rumput laut dan surimi lele berpengaruh terhadap citarasa bakso ikan lele, dimana nilai sig $(0,002 \leq$ 0,05), kemudian berdasarkan uji lanjut 
BNT rasa bakso ikan lele diperoleh bahwa perlakuan P1 terhadap P2 berbeda nyata dimana nilai sig $0,005 \leq 0,05$ sedangkan P1 terhadap P3, P4 dan P5 tidak berbeda nyata dengan nilai sig $\geq 0,05$. Rasa merupakan faktor penentu daya terima konsumen terhadap produk pangan. Penilian citarasa menggunakan alat indera manusia dengan 4 jenis rasa yaitu asin, asam, manis dan pahit (Winarno, 1997). Rasa bakso dibentuk oleh berbagai rangsangan bahkan dipengaruhi oleh aroma dan warna. Rasa bakso secara umum ada 4 rasa yaitu keasinan, kegurihan dan pedas serta rasa daging yang menjadi komposisi utama bahkan ciri khas bakso tersebut.

\section{KESIMPULAN DAN SARAN}

Komposit surimi lele dan bubur rumput laut terhadap bakso ikan disimpulkan bahwa pada uji protein semua perlakuan memenuhi Syarat Mutu Bakso Ikan SNI No. 01-3818:2014. Uji organoleptik memiliki nilai kesukaan panelis terbaik pada perlakuan $10 \%$ bubur rumput laut dan $65 \%$ surimi lele.

Disarankan bahwa formula terbaik untuk digunakan pada pembuatan bakso ikan lele dan rumput laut dengan komposit surimi $65 \%$ dan bubur rumput laut Eucheuma cottoni 10\%, serta tepung tapioka $25 \%$.

\section{DAFTAR PUSTAKA}

Agustina W. 2015. Bakso Ikan Lele, Skripsi Fakultas Pertanian Jurusan Agroteknologi. Sekolah Tinggi Pertanian Dharma Wacana Metro Anggadiredja JT. 2011. Laporan Forum Rumput Laut. Pusat Riset Pengolahan Produk dan Sosial Ekonomi Kelautan dan Perikanan. Jakarta.

Anggraeni, F. N., Suryaningsih, L., \& Putranto, W. S. (2020). Pengaruh Penambahan Rumput Laut (Eucheuma cottonii) Pada Pembuatan Bakso Puyuh Terhadap Sifat Fisik dan Akseptabilitas. Jurnal teknologi Hasil Peternakan, 1(2):5566.

AOAC, 1996. Soedarnaji, S., Bambang Haryono., dan Suhadi., 1989. Analisa Bahan Makanan dan Pertanian. Liberty Yokyakarta Bekerja Sama dengan Pusat Antara Univ. Pangan dan Gizi Universitas Gadja Mada, Yokyakarta.

Aprita, I.R,. Irhami, C,. Anwar1. Salima R. 2020. Diversifikasi Pembuatan Bakso Surimi Ayam dengan penambahan Ubi Jalar (Ipomoea batatas L).

Astawan, M., Wresdiyati, T. \& Koswa-ra, S. (2004). Pemanfaatan Iodi-um dan Serat Pangan dari Rum-put Laut untuk Peningkatan Ke-cerdasan dan Pencegahan Pe-nyakit Degeneratif. Laporan Ak-hir Penelitian Hibah Bersaing Ke 11 Tahun 2003 s/d 2004. LPPM IPB. Bogor.

Iswendi, Yusmaita E., Dewi A. Pangestuti. 2019. Uji Organoleptik Sari Jagung Di Laboratorium Kimia FMIPA UNP.

Fatmawati, Aqmal A., Rampeng. 2018. Pengaruh Konsentrasi Rumput Laut (Kappaphycusalvarezii) Terhadap Tekstur Bakso Ikan Alu-Alu (Sphyraenagenie). Jurnal Ecosystem Volume 18, Nomor 1. 
Fatmawati, Lahming, A.R. Asrip., P. Nurlita. 2020. Farmer's Behavior in Managing Postharvest in South Sulawesi, Indonesia. Advances in Social Science, Education and Humanities Research, volume 481.

Herawati. 2008. Produksi Karkas, Hasil Olahan, dan Perubahan Histologi Organ dan Jaringan Ayam Broiler dengan Suplemen Fitobiotik Jahe Merah. Disertasi. Yogyakarta: Program Studi Ilmu Peternakan Sekolah Pascasarjana Universitas Gadjah Mada.

Laksono UT, Suprihatin, Nurhayati T, Romli M. 2019. Peningkatan kualitas tekstur surimi ikan malong dengan sodium tripolifosfat dan aktivator transglutaminase. Jurnal Pengolahan Hasil Perikanan Indonesia. 22(2): 198-208. http://ejournal-balitbang.kkp.go.id. Diakses 8 Agustus 2021.

Maharaja, Lisa M. 2008. "Penggunaan Campuran Tepung Tapioka Dengan Sagu dan Natrium Nitrat Dalam Pembuatan Bakso Surimi Sapi". Skripsi.Sumatera Utara: Universitas Sumatera Utara.
Okada, N., Seehausen, O., Terai, Y., Magalhaes, I. S., Carleton, K. L., Mrosso, H. D., \& Miyagi, R., 2008. Speciation through sensory drive in cichlid fish. Nature, 455(7213), 620626.

Pinardi J., Widawti L., Nur'ain H,. 2020. Karakteristik Mutu Sosis Ayam dengan Variasi Subtitusi Kacang Merah (Phase vulgaris L). https://journals.unihaz.ac.id/index.p hp/agroqua/article/view/1480

Diakses 17 Agustus 2021.

Probosari E,. 2019. Pengaruh Protein Diet Terhadap Indeks Glikemik. JNH (Journal of Nutrition and Health) Vol.7 No.1.

Potter, Norman N, and Joseph $\mathrm{H}$. Hotchkiss. 2012. Food Science 5th Edition. New York: Chapman \& Hall.

Whistler, R. L. 1984. History and Future Expectation of Starch Uses, in r.l. Whistler, J. N. Bemiller, \& e. F. Paschall (eds.), Starch Chemistry and Technology, New York: Academic Press. 